\title{
COMPARATIVE STUDY OF HEALTH STATUS OF PRIMARY SCHOOL CHILDREN IN RURAL AND URBAN AREA OF KARIMNAGAR DISTRICT (ANDHRA PRADESH) INDIA
}

\author{
Mohammed Kamran Shaikh1, Mohammed Naushad Alam², Dhiraj Bhawnani³, Sita Rama Rao ${ }^{4}$ Kiran G. Makade \\ ${ }^{1}$ Assistant Professor, Department of Community Medicine, Government Medical College, Rajnandgaon, India. \\ ${ }^{2}$ Assistant Professor, Department of Community Medicine, Government Medical College, Rajnandgaon, India. \\ ${ }_{3}^{3}$ Assistant Professor, Department of Community Medicine, Government Medical College, Rajnandgaon, India. \\ 4 Professor, Department of Community Medicine, PIMS, Karimnagar, Andhra Pradesh. \\ ${ }_{5}^{5}$ Associate professor, Department of Community Medicine, Government Medical College, Rajnandgaon.
}

\begin{abstract}
Under five years children are targeted for priority care under various maternal and child health programmes, but this age group (5-15 years) remain neglected. School health services provide an ideal platform to detect the health problems early and treat them. Early detection of the morbidities through regular survey helps in prompt treatment and prevention of serious complications.
\end{abstract}

\section{MATERIAL AND METHODS}

The current descriptive, cross-sectional observational study was conducted in Pratima Institute of Medical Science, Karimnagar, Andhra Pradesh, India, during study period from November 2011 to October 2012 in selected government primary schools from urban and rural areas of Karimnagar Districts. The total sample size was 820. Verbal informed consent was obtained from parents. Standard operational definitions were formulated (formulated) made to assess health status. Data were analysed using chi-square test (Qualitative test).

\section{RESULTS}

Out of the total study subjects, females were more than males. Overall, majority belonged to lower socio-economic status (63.90\%). About half of subjects (49.75\%) were practicing handwashing before food. Around 38.29\% were practicing handwashing after defecation in urban and rural area (42.19\% and 34.39\% respectively). Common presenting symptoms among the study subjects were common cold (34.26\%), toothache (33.17\%), headache (27.31\%), pallor (39.14\%), and diminished vision $13.29 \%$. Pyorrhoea was the common dental health problems (13.04\%).

\section{CONCLUSIONS}

Morbidities and under nutrition were the key findings of the present study along with poor personal hygiene especially in rural areas.

\section{KEYWORDS}

School Children, Health Status, Hygiene, Urban, Rural.

HOW TO CITE THIS ARTICLE: Shaikh MK, Alam MN, Bhawnani D, et al. Comparative study of health status of primary school children in rural and urban area of Karimnagar district (Andhra Pradesh) India. J. Evolution Med. Dent. Sci. 2016;5(62):4365-4368, DOI: $10.14260 /$ jemds/2016/996

\section{INTRODUCTION}

Children are not only divine gifts, but also the future of a nation and hope of the world. They are the country's biggest human investment for development. So far, our country has made little progress in improving the health condition of our school children when compared to the developed countries. It is estimated that every child in India has some sign of ill health.[1] School age children have not received as much attention from health providers/planners as the under-fives. In an international workshop at Kentucky, USA in 1994, it was agreed that there was a dearth of information on the health status of school age children from developing countries particularly at the community level. Under five years children are targeted for priority care under various maternal and child health programmes, but these age groups (5-15 years) remain

Financial or Other, Competing Interest: None.

Submission 08-06-2016, Peer Review 20-07-2016,

Acceptance 27-07-2016, Published 03-08-2016.

Corresponding Author:

Dr. Mohammed Kamran Shaikh,

Plot No. 18,

New Mankapur

Nagpur-30.

E-mail:mdkamransk@gmail.com

DOI: $10.14260 /$ jemds $/ 2016 / 996$ neglected. [2] Early detection of the morbidities through regular survey helps in prompt treatment and prevention of serious complications. After independence, several steps were taken for the improvement of the health situation and well-being of the children. India is home to the largest number of children in the world, larger than China.[3] The population of children in the age group 0-14 for India in 2010 was estimated as 374 million as compared to 269 million in China. In India, about 1.83 million children die annually before completing their fifth birthday-most of them due to preventable causes. ${ }^{[4]}$ Extensive surveys have been carried out in different parts of the country and the findings show that sickness, morbidity, and mortality rates in India are among the highest in the world.[5] These health problems can make learning difficult and may seriously hamper the educational process and the child's intellectual growth and may also handicap the child for life (Consider reframing). Keeping all these facts in view, a need was felt to carry out a survey of the health status of primary school children. School age is a critical time in the development of a human being and the school setting provides a strategic point of entry for improving children's health, self-esteem, life skills, and behaviour. School children are also one of the most accessible groups for treatment and healthcare can be integrated efficiently with education programmes. School 
health services provide an ideal platform to detect the health problems early and treat them.[6] With the above background, the present study was planned to assess the health status of primary schools children at Karimnagar District (Andhra Pradesh), India.

\section{MATERIAL AND METHODS}

The current cross-sectional observational study was conducted in Pratima Institute of Medical Science, Karimnagar (Andhra Pradesh), India, during period from November 2011 to October 2012. Selected government primary schools from urban and rural areas of Karimnagar Districts were considered for the study. Predesigned and pretested proforma was used for data collection. A total sample of 820 students was selected for the final study by using following formula $n=4 p q / d 2$.

Where $n$ is the sample size, $p$ is the prevalence, $q$ is $(1-p)$, and $\mathrm{d}$ is precision.

The calculated sample size was 384 . Five percent was added to this to account for nonresponse bringing the total to 404 , which was rounded off to 410 . The number was doubled to enable an urban rural comparison bringing the total sample size to 820. Simple random sampling was used for selection of desired sample size. Ethical consideration was obtained from institutional ethical committee.

\section{Inclusion Criteria}

1. Children enrolled in registers of government primary schools in Karimnagar District.

2. Children in the age group of 6 to 11 years.

3. Children who were present in at least two visits and willing to participate in study.

\section{Exclusion Criteria}

1. Children who were unreachable in spite of two school visits.

2. Children and parents who were unwilling to give consent or co-operate for the interview.

\section{METHODOLOGY}

List of government schools was obtained from the District Education Office of Karimnagar District. There were 45 schools in the urban area and 81 schools in rural areas of Karimnagar District. To work out equal number of children from both area, school selected in urban area were twice of the figure selected in rural area. All children in these schools were selected for the study and 820 children were included in the final analysis. Purpose of study was explained to teachers and children and their parents. Teachers were asked to inform the parent to be present on day of examination at school. Verbal informed consent was obtained from parents. Children were interviewed using predesigned pretested proforma and clinically examined with the assistance of teachers. Family and socioeconomic history was obtained from parents. Every student was subjected to a thorough physical and systemic examination including a careful clinical history. The physical appearance and signs of morbidities and deficiencies was noted by the investigator using a checklist for signs of various diseases. Standard operational definitions were used to assess health status. A brief health education session was delivered to the teachers and students and their parents. Data were analysed using Epi Info (Version 7) software and statistical measures were obtained using chi-square test. P value $<0.05$ was considered as statistically significant.

\section{RESULTS}

Out of the total study subjects, females were more than males (51.09\% and $48.90 \%$ respectively), whereas in rural area females were $54.39 \%$ and in urban area males were $52.19 \%$. Majority of the subjects were in the 10-11 years age group $(35.24 \%)$. In rural area, older children $10-11$ years were in majority (39.75\%) whereas in urban area majority belongs to 8-9 years of age group (37.07\%). Majority lower socioeconomic status (63.90\%). Similar findings were observed in both rural and urban area. Majority belong to low socioeconomic status $61.28 \%$ and $66.58 \%$ respectively. Majority of the subjects (52.68\%) residing in joint family. Joint family concept was practised in rural area $55.85 \%$ whereas nuclear concept was predominant in urban area $50.48 \%$. Majority of subjects $(72.92 \%)$ were belonging to second birth order. Similar trend was observed in both rural and urban area 77.31\% and $68.53 \%$ respectively. (Table 1 ).

About half of subjects $(49.75 \%)$ were practicing handwashing before food. This practice was almost similar in both urban and rural area $49.26 \%$ and $50.24 \%$ respectively. Only $38.29 \%$ were practicing handwashing after defecation. In urban and rural area, $42.19 \%$ and $34.39 \%$ respectively. Overall hygiene practices related to tooth brushing was $47.43 \%$ [More in urban (51.70\%) than rural area (43.17\%)] Daily bathing practice was markedly high $90.60 \%$ (Urban 93.17\% and rural 88.04\%). (Table 2).

Mixed diet practice (Predominantly veg) was $77.80 \%$ (77.07\% in rural and $78.53 \%$ in urban). Overall, $75.97 \%$ subjects were consuming meal 3 times a day. Similar trend were observed both in rural and urban area $184.63 \%$ and $67.31 \%$ respectively). A significant proportion $79.87 \%$ were using mid-day meal. Proportion was more in rural $83.56 \%$ than urban area $76.09 \%$ respectively. (Table 3).

Common presenting symptoms among the study subjects were common cold $(34.26 \%)$, toothache $(33.17 \%)$, headache (27.31\%), cough $(26.82 \%)$, pallor $(39.14 \%)$, and diminished vision $13.29 \%$. Among dermatological signs, pyoderma followed by scabies and taeniasis were the predominant (More in rural area than urban area). Nasal discharge, tonsillitis, and wax were the common ENT problems 27.92\%, 21.58\%, and $19.51 \%$, respectively (More in rural than urban area) (Table$4,5)$.

Pyorrhoea was the common dental health problems (13.04\%). Dental caries was prevailing in rural area whereas pyorrhoea among urban area $21.21 \%$ and $21.21 \%$, respectively. Respiratory problems $(4.75 \%)$ were more than cardiac problems (1.58\%). Prevalence of respiratory problems was more in rural $(5.60 \%)$ than urban $(3.90 \%)$. Overall, vitamin D deficiency was most common (5.48\%) (Predominant in rural) whereas in urban area vitamin $\mathrm{C}$ deficiency was the major problems (6.09\%). (Table 6). 


\begin{tabular}{|c|c|c|c|}
\hline Variable & Urban & Rural & Total \\
\hline \multicolumn{5}{|c|}{ Gender } \\
\hline Male & $214(52.19)$ & $187(45.60)$ & $401(48.90)$ \\
\hline Female & $196(47.80)$ & $223(54.39)$ & $419(51.09)$ \\
\hline \multicolumn{5}{|c|}{ Age (In years) } \\
\hline $6-7$ & $132(32.19)$ & $140(34.14)$ & $272(33.17)$ \\
\hline $8-9$ & $152(37.07)$ & $107(26.09)$ & $259(31.58)$ \\
\hline $10-11$ & $126(30.73)$ & $163(39.75)$ & $289(35.24)$ \\
\hline \multicolumn{5}{|c|}{ SES } \\
\hline Upper & $54(13.17)$ & $26(6.34)$ & $80(9.75)$ \\
\hline Middle & $83(20.24)$ & $133(32.43)$ & $216(26.34)$ \\
\hline Lower & $273(66.58)$ & $251(61.21)$ & $524(63.90)$ \\
\hline \multicolumn{5}{|c|}{ Type of Family } \\
\hline Joint & $203(49.51)$ & $229(55.85)$ & $432(52.68)$ \\
\hline Nuclear & $207(50.48)$ & $181(44.14)$ & $388(47.31)$ \\
\hline \multicolumn{5}{|c|}{ Birth Order } \\
\hline 1 & $61(14.87)$ & $42(10.24)$ & $103(12.56)$ \\
\hline 2 & 281(68.53) & 317(77.31) & $598(72.92)$ \\
\hline 3 & $68(16.58)$ & $51(12.43)$ & $119(14.51)$ \\
\hline Table 1: Demographic Profile of Study Population \\
\hline \multicolumn{4}{|c|}{}
\end{tabular}

\begin{tabular}{|c|c|c|c|}
\hline Hygiene Status & Rural & Urban & Total \\
\hline \multicolumn{4}{|c|}{ Handwashing before Food } \\
\hline Yes & $206(50.24)$ & $202(49.26)$ & $408(49.75)$ \\
\hline No & $204(49.75)$ & $208(50.73)$ & $412(50.24)$ \\
\hline \multicolumn{4}{|c|}{ Handwashing after Defecation } \\
\hline Yes & $141(34.39)$ & $173(42.19)$ & $314(38.29)$ \\
\hline No & $269(65.60)$ & $237(66.58)$ & $506(61.70)$ \\
\hline \multicolumn{4}{|c|}{ Tooth brushing } \\
\hline Yes & $177(43.17)$ & $212(51.70)$ & $389(47.43)$ \\
\hline No & $233(56.82)$ & $198(48.29)$ & $431(52.56)$ \\
\hline \multicolumn{4}{|c|}{ Daily Bathing } \\
\hline Yes & $361(88.04)$ & $382(93.17)$ & $743(90.60)$ \\
\hline No & $49(11.95)$ & $28(6.82)$ & $77(9.39)$ \\
\hline Table 2: Distribution as per Personal Hygiene Status \\
\hline
\end{tabular}

\begin{tabular}{|c|c|c|c|}
\hline Dietary Status & Rural & Urban & Total \\
\hline \multicolumn{5}{|c|}{ Type of Diet } \\
\hline Vegetarian & $88(21.46)$ & $94(22.92)$ & $182(22.19)$ \\
\hline Mixed & $322(78.53)$ & $316(77.07)$ & $638(77.80)$ \\
\hline \multicolumn{4}{|c|}{ Frequency of Meal/Day } \\
\hline 2 & $51(12.43)$ & $45(10.97)$ & $96(11.70)$ \\
\hline 3 & $347(84.63)$ & $276(67.31)$ & $623(75.97)$ \\
\hline 4 & $12(2.92)$ & $89(21.70)$ & $101(12.31)$ \\
\hline \multicolumn{4}{|c|}{ Consuming Mid-Day Meal } \\
\hline Yes & $343(83.56)$ & $312(76.09)$ & $655(79.87)$ \\
\hline No $67(16.34)$ & $98(23.90)$ & $165(20.12)$ \\
\hline Table 3: Distribution as per Dietary Status \\
\hline \multicolumn{4}{|c|}{}
\end{tabular}

\begin{tabular}{|c|c|c|c|}
\hline Symptoms & Rural & Urban & Total \\
\hline Fever & $64(47.76)$ & $70(52.23)$ & $134(16.34)$ \\
\hline Throat Pain & $108(63.15)$ & $63(36.84)$ & $171(20.85)$ \\
\hline Cough & $104(47.27)$ & $116(52.72)$ & $220(26.82)$ \\
\hline $\begin{array}{c}\text { Breathing } \\
\text { Difficulty }\end{array}$ & $90(48.91)$ & $94(51.08)$ & $184(22.43)$ \\
\hline Ear Discharge & $107(56.91)$ & $81(43.08)$ & $188(22.92)$ \\
\hline Rash & $52(46.84)$ & $59(53.15)$ & $111(13.53)$ \\
\hline $\begin{array}{c}\text { Abdominal } \\
\text { Pain }\end{array}$ & $91(59.09)$ & $63(40.90)$ & $154(18.78)$ \\
\hline Loose Motion & $97(55.74)$ & $77(44.25)$ & $174(21.21)$ \\
\hline Common Cold & $159(56.58)$ & $122(43.41)$ & $281(34.26)$ \\
\hline Toothache & $146(53.67)$ & $126(46.32)$ & $272(33.17)$ \\
\hline
\end{tabular}

\begin{tabular}{|c|c|c|c|}
\hline Headache & $109(48.66)$ & $115(51.33)$ & $224(27.31)$ \\
\hline $\begin{array}{c}\text { Passage of } \\
\text { Worm }\end{array}$ & $95(62.09)$ & $58(37.90)$ & $153(18.65)$ \\
\hline Table 4: Symptoms-Wise Distribution Based on Previous \\
History \\
\hline
\end{tabular}

\begin{tabular}{|c|c|c|c|c|}
\hline \multirow{2}{*}{ Eye Sign } & \multicolumn{2}{|c|}{ Present } & \multirow{2}{*}{$\begin{array}{c}\begin{array}{c}\text { Total } \\
(n=820)\end{array} \\
\text { Present }\end{array}$} & \multirow{2}{*}{\begin{tabular}{|c|} 
Chi-square, \\
d.f., \\
P value \\
\\
\end{tabular}} \\
\hline & $\begin{array}{c}\text { Rural } \\
(n=410)\end{array}$ & $\begin{array}{c}\text { Urban } \\
(n=410)\end{array}$ & & \\
\hline Redness & $40(9.75)$ & $7(1.70)$ & $47(5.73)$ & \multirow{5}{*}{$\begin{array}{c}20.426,4, \\
<0.001 \\
{[\text { Highly }} \\
\text { Significant] }\end{array}$} \\
\hline Discharge & $46(11.21)$ & $13(3.17)$ & $59(7.91)$ & \\
\hline Vision Loss & $58(14.14)$ & $51(12.43)$ & $109(13.29)$ & \\
\hline Vit. A Deficiency & $5(1.21)$ & $3(0.73)$ & $8(0.97)$ & \\
\hline Pallor & \multicolumn{3}{|c|}{\begin{tabular}{|l|l|l|}
$197(48.04)$ & $124(30.24)$ & $321(39.14)$ \\
\end{tabular}} & \\
\hline \multicolumn{5}{|c|}{ Dermatological Sign } \\
\hline Hair Sign & $25(6.09)$ & $6(1.46)$ & $31(3.78)$ & \multirow{7}{*}{$\begin{array}{c}13.927,6 \\
<0.05 \\
\text { Significant] }\end{array}$} \\
\hline Scabies & $59(14.39)$ & $34(8.29)$ & 93(11.34) & \\
\hline Taeniasis & 63(15.36) & $13(3.17)$ & $76(9.26)$ & \\
\hline $\begin{array}{l}\text { Hypopigmented } \\
\text { Patch } \\
\end{array}$ & $32(7.80)$ & $13(3.17)$ & $45(5.48)$ & \\
\hline Eczema & $21(5.12)$ & $14(3.41)$ & $35(4.26)$ & \\
\hline Rash & $56(13.65)$ & $18(4.39)$ & $74(9.02)$ & \\
\hline Pyoderma & $98(23.90)$ & $28(6.82)$ & $126(15.36)$ & \\
\hline \multicolumn{5}{|c|}{ ENT } \\
\hline Discharge & $59(14.39)$ & $34(8.29)$ & 93(11.34) & \multirow{7}{*}{$\begin{array}{c}20.925,6 \\
<0.001 \\
{[\text { Highly }} \\
\text { Significant] }\end{array}$} \\
\hline Wax & 102(24.87) & $58(14.14)$ & $160(19.51)$ & \\
\hline Parotid Enlargement & $2(0.48)$ & 0 & $2(0.24)$ & \\
\hline \begin{tabular}{|c|} 
Nasal \\
Discharge/Congestio \\
$\mathrm{n}$ \\
\end{tabular} & $145(3$ & $84(20.48)$ & $229(27.92)$ & \\
\hline $\begin{array}{l}\text { Deviated Nasal } \\
\text { Septum } \\
\end{array}$ & $95(23.17)$ & $51(12.43)$ & $146(17.80)$ & \\
\hline Tonsillitis & $131(31.95)$ & $46(11.21)$ & $177(21.58)$ & \\
\hline Pharyngitis & $51(12.43)$ & $6(1.46)$ & $57(6.95)$ & \\
\hline
\end{tabular}

\begin{tabular}{|c|c|c|c|c|}
\hline \multirow{2}{*}{$\begin{array}{l}\text { Dental and } \\
\text { Gingival }\end{array}$} & \multicolumn{2}{|c|}{ Present } & \multirow{2}{*}{$\begin{array}{c}\begin{array}{c}\text { Total } \\
(\mathrm{n}=820)\end{array} \\
\text { Present }\end{array}$} & \multirow{2}{*}{$\begin{array}{l}\text { Chi-square, } \\
\text { d.f., p value }\end{array}$} \\
\hline & $\begin{array}{c}\text { Rural } \\
(n=410)\end{array}$ & $\begin{array}{c}\text { Urban } \\
(n=410)\end{array}$ & & \\
\hline Dental Caries & $87(21.21)$ & $26(6.34)$ & 113(13.78) & \multirow{3}{*}{$\begin{array}{c}78.575,2, \\
<0.001 \\
\text { [Highly } \\
\text { Significant] }\end{array}$} \\
\hline Pyorrhoea & $20(4.87)$ & $87(21.21)$ & $107(13.04)$ & \\
\hline Gingivitis & $25(6.09)$ & $13(3.17)$ & $38(4.63)$ & \\
\hline \multicolumn{5}{|c|}{ Cardiorespiratory } \\
\hline Respiratory & $23(5.60)$ & $16(3.90)$ & $39(4.75)$ & \multirow{2}{*}{$\begin{array}{l}0.65,1 \\
>0.05\end{array}$} \\
\hline Cardiovascular & $6(1.46)$ & $7(1.70)$ & $13(1.58)$ & \\
\hline \multicolumn{5}{|c|}{ Vitamin Deficiency } \\
\hline Vit. B & $19(4.63)$ & $24(5.85)$ & $43(5.24)$ & \multirow{3}{*}{$\begin{array}{c}8.97,2, \\
<0.01 \\
{[\text { Significant }]}\end{array}$} \\
\hline Vit. C & $19(4.63)$ & $25(6.09)$ & $44(5.36)$ & \\
\hline Vit. D & $32(7.80)$ & $13(3.17)$ & $45(5.48)$ & \\
\hline & $\begin{array}{r}\text { ibutio } \\
\text { Vi }\end{array}$ & s per $D$ & $\begin{array}{l}\text { al and } G \\
\text { er }\end{array}$ & val and \\
\hline
\end{tabular}

\section{DISCUSSION}

Many previous studies have been conducted with comparable findings to the present study. In the current study, most common personal hygiene-related problems were handwashing after defecation (61.71\%), before food $(50.25 \%)$, and tooth brushing (52.57\%). While Kalaiselvan G et al[7] shows untrimmed and dirty nails were the most common personal hygiene-related problem in their study. 
Daily bathing practice was markedly high $90.60 \%$ in the current study.

The most common presenting symptoms were common cold $34.26 \%$, toothache $33.17 \%$, headache $27.31 \%$, and cough $26.82 \%$. Pallor followed by vision loss were $39.14 \%$ and $13.29 \%$ respectively whereas Panda et al[8] shows the problem of anaemia was present in overall $26 \%$, which is lower than the finding of the current study. Another study by Bhandari et al[9] shows pediculosis (26.2 per cent), dental caries (18.1 per cent) and waxy ear (17.1 per cent) were the common health problems. Shakya S R et al[10] observed parasitic infestation of $65.8 \%$ and anaemia of $58 \%$, skin diseases (20\%), dental caries (19.8\%), and lymphadenopathy (10.5\%).

In the present study, vitamin D deficiency was most common (5.48\%), predominant in rural, whereas in urban area, vitamin C deficiency was the major problems (6.09\%). While Aspatwar AP et al[11] observed $4.8 \%$ of the children were suffering from one or the other signs of vitamin A deficiency in their study.

\section{CONCLUSIONS}

Morbidities and under nutrition were the key findings of the present study along with poor personal hygiene especially in rural areas.

\section{Strength}

In the present study, the variables were compared among urban and rural setting, which was done in a very limited number of previous studies.

Findings of the present study will provide baseline data for further research and also helpful for health planners in priority setting and resource allocation.

\section{LIMITATIONS}

Because of limited resources, children found sick during study could not be treated at the same time, but such children were referred to nearest health facility for management.

Further studies in the similar context can be undertaken on large scale to get more valid results.

\section{RECOMMENDATIONS}

Hence, emphasis on primordial and primary preventive measures like health education should be given for this section of students. In this respect, not only parents, but school teachers should be trained adequately. Health education, personal hygiene education, and nutrition education maybe made as a part of school curriculum apart from regular education activities.

\section{REFERENCES}

1. Dambhare DG, Bharambe MS, Mehendale AM, et al. Nutritional status and morbidity among school going adolescents in Wardha, a peri-urban area. Online Journal Health Allied Sciences 2010;9(2):1-3.

2. Bundy DAP, Guyatt HL. The health of school age children: report of a workshop. Parasitology Today 1995;11:166-7.

3. World population prospects: 2008 revision population database.

4. State of the World's Children Report: UNICEF 2010.

5. Taneja MK, Sandell J, Shukla PL. Health status of school children in western UP. Indian Journal of Paediatrics 1978;45(11):359-63.

6. Bhagwat S, Kulkarni N, Raje S, et al. Some neglected aspects of school health checkups. Indian Journal of Community Medicine 2004;29:29-33.

7. Kalaiselvan G, Kumar A, Dongre AR, et al. Nutritional status and personal hygiene related morbidities among rural school children in Puducherry, India. Nat J Res Com Med 2012;1(2):96-100.

8. Panda P, Benjamin AJ, Singh S, et al. Health status of school children in Ludhiana City. Indian Journal of Community Medicine 2000;25(4):150-5.

9. Bhandari N, Shrestha GK. Nutritional status and morbidity pattern in school age children in Nepal. Journal of College of Medical Sciences, Nepal 2012;8(2):12-6.

10. Shakya SR, Bhandary S, Pokharel PK. Nutritional status and morbidity pattern among governmental primary school children in the eastern Nepal. Kathmandu University Medical Journal 2004;2(8):307-14.

11. Aspatwar AP, Bapat MM. Vitamin A status of socioeconomically backward children. Indian J Paediatr 1995;62(4):427-32. 